\title{
ОБГРУНТУВАННЯ ЗНАЧЕННЯ ВЕБ-ПОРТАЛУ НАВЧАЛЬНО- МЕТОДИЧНИХ МАТЕРІАЛІВ ДЛЯ ТЕОРЕТИЧНОЇ ТА ПРАКТИЧНОЇ ПІДГОТОВКИ СТУДЕНТІВ-ІНОЗЕМЦІВ У ВИВЧЕННІ ІНОЗЕМНОЇ (УКРАЇНСЬКОӦ) МОВИ ЗА ПРОФЕСІЙНИМ СПРЯМУВАННЯМ
}

\author{
В. П. Марценюк, Г. В. Жмудська
}

ДВНЗ “Тернопільський держсавний медичний університет імені І. Я. Горбачевського МОЗ Украйни”

\section{SUBSTANTIATION OF IMPORTANCE OF EDUCATIONAL AND METHODOLOGICAL MATERIALS WEB-PORTAL FOR THEORETICAL AND PRACTICAL TRAINING OF FOREIGN STUDENTS IN STUDYING OF PROFESSIONAL FOREIGN (UKRAINIAN) LANGUAGE}

\author{
V. P. Martsenyuk, H.V.Zhmudska \\ SHEI "Ternopil State Medical University by I. Ya. Horbachevsky of MPH of Ukraine"
}

\begin{abstract}
У статті обгрунтовується ефективність використання Веб-порталу навчально-методичних матеріалів для теоретичної та практичної підготовки студентів-іноземців у вивченні іноземної (української) мови за професійним спрямуванням.

The article deals with the importance of Web-portal of educational and methodological materials for theoretical and practical training of foreign students in studying of Professional Foreign (Ukrainian) Language.
\end{abstract}

Вступ. Сучасний етап розвитку українського суспільства характеризується виведенням освіти в Україні на рівень розвинутих країн світу. Застосування найновіших засобів інформаційної технології в різних галузях людської діяльності, в тому числі і в освіті, набуває все більшої актуальності. У вітчизняних та зарубіжних виданнях комп'ютеризація навчального процесу розглядається як один із актуальних факторів організації навчання того чи іншого предмета.

Вивчення української мови займає одне 3 найважливіших місць у сфері освіти, адже вона є мовою державних органів влади, мовою засобів масової інформації, мовою науки і освіти, мовою художньої літератури, засобом спілкування людей у виробничій i культурній сферах. Ці функції української мови актуальні не тільки для носіїв мови, а й для іноземців, які тут здобувають освіту, оскільки іноземні студенти використовують мову і як інструмент набуття професійних знань, і як засіб повсякденного спілкування.

Оскільки студенти-медики знаходяться в іншомовному середовищі, у якому вони повинні набувати практичних навичок у своїй професії, спілкуючись 3 українськими хворими, знання української мови та володіння професійною термінологією є невід'ємною частиною їх професійної компетенції. Навчальні ма- теріали, представленні на Веб-порталі нашого університету, відіграють у цьому немаловажну роль. Адже застосування мультимедійних засобів у вивченні іноземної мови дає можливість студентам ознайомитись та засвоїти культурологічну інформацію, яка включає в себе мовний етикет, особливості мовленнєвої поведінки саме в їх професійній сфері спілкування. На сучасному етапі світового розвитку зростає потреба в кваліфікованих фахівцях, які мають високий рівень мовної підготовки.

Активному впровадженню інноваційних технологій у вивченні іноземної (української) мови (далі ІУМ) в останні роки приділяється велика увага. Різноманітні електронні підручники, контролюючі програми, електронні словники, редактори текстів, енциклопедичні програми можуть бути успішно використані під час вивчення ІУМ. Саме цим зумовлена увага педагогів та методистів до інновацій [1, 3-6].

Хоча методика викладання ІУМ порівняно молода наука, на сьогодні вже $є$ значна кількість праць, у яких розглядається сутність інновацій у викладанні гуманітарних дисциплін у вищій школі. Серед найбільш вагомих праць, присвячених проблемам впровадження інформаційно-комунікативних технологій у навчальний процес в Україні, можна виділити

() В. П. Марценюк, Г. В. Жмудська 
П. Дмитренка, М. Жалдака, В. Кухаренка, В. Олійника, В. Глушкова, М. Згуровського, В. Михайленка. Проблеми використання інноваційних технологій під час викладання іноземних мов розглядали О. Коваленко, Є. Можар, Л. Олійник та інші. Проблемою використання інноваційних методів займались такі вчені, як О. Арламов, М. Бургін, В. Журавльов, В. Загвязинський, Н. Юсуфбекова та інші. Серед науковців, які працювали над проблемою впровадження та використання комп'ютерних технологій у вивченні іноземних мов, слід назвати О. Кужель, Т. Коваль.

Мета даної роботи - дослідити ефективність використання студентами-іноземцями Веб-порталу навчально-методичних матеріалів для теоретичної та практичної підготовки з курсу іноземної (української) мови професійного спрямування у сукупності з традиційними формами та методами викладання дисциплін.

Основна частина. 3 появою швидкісних каналів Інтернет, що дозволили передачу відео, починаючи 3 2000-х років, створюються Веб-портали різних навчальних матеріалів. Одним із перших такий Вебпортал було створено у Тернопільському державному медичному університеті, на якому сьогодні представлено понад 23 тисячі навчально-методичних матеріали, включаючи матеріали для підготовки до лекцій та практичних занять, навчальні відеофільми та відеозаписи, електронні версії підручників та посібників для вивчення різних медичних, стоматологічних та фармацевтичних дисциплін. Суттєву нішу тут займають матеріали для вивчення іноземної (української) мови професійного спрямування.

Підготувати в короткий термін фахівця, який добре володіє іноземною мовою, досить складно, оскільки в навчальній програмі немовного вузу на вивчення іноземної мови відводиться мінімальна кількість годин. Щоб досягти поставленої мети навчити студента-іноземця протягом обмеженого навчальними рамками часу розмовляти, використовуючи професійну лексику, і розуміти мову ії носіїв можна, тільки поєднуючи традиційні та інноваційні методи.

Термін “інновація” латинського походження й о3начає зміну, введення нового. У педагогіці він позначає нововведення, оновлення процесу навчання. Інноваційні технології містять такі підходи до викладання іноземних мов, як: інтерактивні методи викладання та використання технічних засобів навчання (комп'ютерних та мультимедійних, мережі Internet) для контролю знань, зберігання і використання навчальних матеріалів [3:10 ].
У методології викладання української мови як іноземної допомагають інтерактивні методи викладання. Інтерактивне навчання можна визначити як взаємодію учасників процесу здобуття знань: студент за допомогою викладача, що володіє методами, спрямованими на оволодіння цими знаннями, набуває необхідних, згідно з навчальною програмою, знань та умінь [4:10].

Інтерактивні методики навчання знайшли своє визнання при викладанні як професійно-орієнтованих дисциплін, наприклад, медичного спрямування [С. Клименко, В. Марциненко, Ю. Мастеров], так і при викладанні гуманітарних дисциплін [О. Біляєв, Е. Вєтрова, Е. Можар, Т. Фоміна, Т. Зеленова та ін.].

Окреме місце серед інтерактивних методик посідають комп' ютерно-інформаційні технології. С чимало досліджень, серед яких праці О. Мінцера, П. Федорука $[8,9]$, що підтверджують їх ефективність при викладанні природничих дисциплін. На жаль, використання комп'ютерних технологій у вивченні іноземної (української) мови у вищих навчальних закладах зараз знаходиться на початковому рівні, що спонукає до проведення досліджень щодо їх ефективності.

Використання інтерактивних методів у педагогічному процесі спонукає викладача до постійної творчості, вдосконалення, зміни, професійного зростання, розвитку. Із застосуванням мультимедійних технологій педагог може подати інформацію в абсолютно новій та ефективній формі, зробити ії більш повною, цікавою та наближеною до тематики, що вивчається. За допомогою мультимедійних технологій можна значно урізноманітнити інформацію та на базі звичайних вправ зробити подачу матеріалу легкою та цікавою. Оволодівши програмою створення презентацій Power Point, викладач сам стає режисером свого заняття. Проста у використанні, ця програма дозволяє створити анімаційний опорний конспект, включити відео- чи аудіофрагмент, зобразити в динаміці якесь явище, подію, що допоможе студентові-іноземцю легко зрозуміти та засвоїти новий лексичний чи граматичний матеріал. Особливо популярним є використання презентацій під час вивчення нової лексики з тем "Моя сім'я”, "Наш університет”, “Магазин”, “Продукти”, “Вулиця”, “Місто”, “Транспорт”, "Пори року" та інші.

Запровадження інноваційних методик та мультимедійних технологій при вивченні ІУМ професійного спрямування дає викладачам можливість подавати матеріал та розробляти завдання таким чином, щоб вони були максимально наближені до реальних ситуацій, які можуть трапитись в їхній професійній діяль- 
ності, що буде значно підвищувати мотивацію студентів.

Для студентів вивчення ІУМ професійного спрямування із застосуванням мультимедійних технологій має певні переваги. Оскільки ці технології нові, тим, хто навчається, цікаво оволодівати нестандартними видами отримання інформації. Студент може самостійно поповнювати свій словниковий запас, як активний, так і пасивний, лексикою сучасної української мови професійного спрямування. В мережі Інтернет студенти можуть слідкувати за змінами в їх професійній сфері, що теж дає поштовх для стійкої мотивації студентів до вивчення ІУМ професійного спрямування.

Щоб допомогти студентам у підготовці до занять з іноземної української мови, на Веб-порталі університету подано велику кількість допоміжних матеріалів. Серед них Календарно-тематичний план проведення практичних занять, Матеріали для підготовки до практичних занять, Методичні рекомендації для студентів, аудіо- та відеоматеріали. Завдяки такому доробку студент завчасно ознайомлений з темою наступного заняття та має достатньо матеріалу для самостійної підготовки, що допоможе йому простіше і краще засвоїти матеріал, який буде подаватися викладачем на занятті.

Для оцінки ефективності використання Веб-порталу навчально-методичних матеріалів для теоретичної та практичної підготовки студентів-іноземців у вивченні ІУМ за професійним спрямуванням ми провели анкетування серед студентів 2 курсу Терно- пільського державного медичного університету. В анкетуванні брали участь 204 студенти, найстаршому з яких 26 років, наймолодшому - 17, переважній кількості студентів 20-22 роки. Кількість осіб жіночої статі складала $44 \%$. Серед досліджуваних було 83 студенти з Іраку та 121 студент з Африки.

На першому етапі дослідження було встановлено ступінь Інтернет-обізнаності. Більшість студентів добре володіла Інтернет-технологіями (рис. 1).

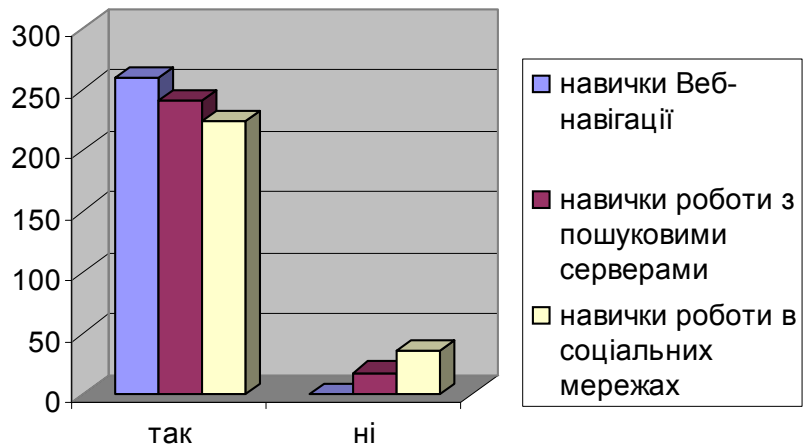

Puc. 1. Показники Інтернет-обізнаності студентів.

На другому етапі дослідження на основі відповідей студентів було визначено ефективність навчально-методичних матеріалів, розміщених на Веб-порталі університету з авторизованим доступом, для підготовки до практичних занять та набуття практичних навичок з курсу “Іноземна українська мова професійного спрямування”. У таблиці наведено результати відповідей на основі запитань щодо загальної характеристики навчального курсу.

\begin{tabular}{|c|c|c|c|}
\hline Питання анкети & так & ні & на $50 \%$ \\
\hline Чи складним був для Вас матеріал курсу? & $21 \%$ & $79 \%$ & - \\
\hline Чи отримали Ви міцні знання з курсу вивчення української мови? & $61 \%$ & $21 \%$ & $18 \%$ \\
\hline Чи отримали Ви ефективні мовні навички з даного курсу? & $88 \%$ & $5,8 \%$ & $6,2 \%$ \\
\hline $\begin{array}{l}\text { Чи допомогли Вам у підготовці до занять матеріали, викладені на Веб- } \\
\text { порталі університету? }\end{array}$ & $64,1 \%$ & $33 \%$ & $2,9 \%$ \\
\hline $\begin{array}{l}\text { Чи складною для Вас була інформація, викладена у навчально-методичних } \\
\text { матеріалах? }\end{array}$ & $9,2 \%$ & $55,8 \%$ & $35 \%$ \\
\hline $\begin{array}{l}\text { Чи повною мірою супроводжувався виклад матеріалу мультимедійними } \\
\text { засобами? }\end{array}$ & $97 \%$ & $2,3 \%$ & - \\
\hline $\begin{array}{l}\text { Чи оперативним був у Вас доступ до сучасних інформаційних джерел } 3 \\
\text { даного курсу? }\end{array}$ & $67,6 \%$ & $11,7 \%$ & $20,7 \%$ \\
\hline $\begin{array}{l}\text { Чи вважаєте Ви ефективним використання Веб-порталу у вивченні } \\
\text { української мови? }\end{array}$ & $47 \%$ & $53 \%$ & \\
\hline
\end{tabular}

Опираючись на відповіді таблиці про складність викладених на Веб-порталі матеріалів 3 курсу "ІУМ професійного спрямування", то з отриманих результатів видно, що студенти-іноземці вважають опанування дисципліни не складним - 79 \% відповідей, але міцні знання отримали всього лише $61 \%$ опитуваних.
У той же час, у значної кількості студентів склалася думка про те, що вивчення гуманітарних дисциплін, зокрема іноземної мови, у ВМНЗ $є$ другорядним. Як наслідок, 33 \% опитуваних вважають, що матеріали, розміщені на Веб-порталі, мало допомагають у вивченні іноземної мови. Незважаючи на це, ефективні 
мовні навички отримали 88 \% опитуваних. Варто зауважити, що такий результат може бути отриманий завдяки живому спілкуванню з викладачем та побутовому спілкуванню з україномовними студентами.

Щодо супроводу матеріалу мультимедійними засобами безпосередньо на занятті, то варто зауважити, що $97 \%$ досліджуваних засвідчили, що виклад матеріалу повною мірою супроводжувався мультимедійними засобами.

Що стосується матеріалів Веб-порталу, то 67 \% вважають доступ до сучасних інформаційних джерел $з$ даного курсу - оперативним.

Однак із вказаними перевагами пов'язані і певні недоліки, наприклад, великий обсяг інформації та їі складність.

Висновки. Використання інноваційних методів значно поліпшує якість презентації навчального матеріалу та ефективність його засвоєння студентами, збагачує зміст освітнього процесу, підвищує мотивацію до вивчення української мови, покращує швидкість засвоєння граматичних конструкцій та накопичення словникового запасу, створює умови для більш тісної співпраці між викладачами і студентами.

\section{Література}

1. Аскоянц П. Г. Основи методики створення та застосування комп'ютерних програм у навчанні іноземних мов / П. Г. Аскоянц, Г. С. Чекаль, П. І. Сердюков. - К. : КДПІ1М, 2004. $-108 \mathrm{c}$.

2. Досвід Віденського медичного університету в реформуванні системи освіти. Перспективи співпраці / за ред. Л. Я. Ковальчука. - Тернопіль : ТДМУ, 2006. -290 с.

3. Інтерактивні технології навчання / авт.-упор. І. І. Дівакова. - Тернопіль : Мандрівець, 2009. -С. 23-27.

4. Кашлев С. С. Технология интерактивного обучения / С. С. Кашлев. - Мінск : Белорусский верасень, 2005.-176 c.

5. Ковальчук Л. Я. Впровадження нової методики навчального процесу в Тернопільському державному медичному університеті імені І. Я. Горбачевського / Л. Я. Ковальчук // Медична освіта. - 2007. - № 2. - С. 16-20.
Вивчення та застосування на практиці інноваційних методологічних підходів з використанням комп'ютерно-інформаційних технологій надають можливість викладачам української мови як іноземної впроваджувати та удосконалювати нові методи роботи.

Аналіз результатів використання Веб-порталу навчально-методичних матеріалів для студентів-іноземців у вивченні ІУМ за професійним спрямуванням свідчить про його важливе значення для ефективної організації навчального процесу на сучасному етапі. Слід відзначити оперативність і новизну представленої для студентів інформації. Порівняно з традиційними підручниками і посібниками, представлена на Веб-порталі інформація дає можливість покращити якість навчального процесу та рівень знань студентів.

Важливим $є$ наповнення Веб-порталу мультимедійними ресурсами, такими, як відео- та аудіозаписи, які використовуються при навчанні усного мовлення.

Слід зазначити, що використання електронних навчальних матеріалів значно зменшує витрати на організацію навчального процесу.

6. Кужель О. М. Використання персонального комп’ютера у вивченні іноземних мов / О. М. Кужель, Т. І. Коваль // Нові інформаційні технології навчання в навчальних закладах України : науково-методичний збірник. Вип. 8: Педагогіка/редкол.: І. І. Мархель (гол. ред.) та ін.-Одеса : Друк, 2001.

7. Марценюк В. П. Впровадження в навчальний процес комп'ютерних технологій / В. П. Марценюк // Медична освіта.-2007. - № 2. - С. 40-41.

8. Мінцер О. П. Роль інноваційних технологій на етапах реформування медичної освіти / О. П. Мінцер // Медична освіта. -2005. - № 2. - С. 128-130.

9. Федорук П. І. Технологія побудови навчального процесу в адаптивних системах дистанційного навчання та контролю знань / П. І. Федорук // Штучний інтелект. -2009. - № 3. - C. $352-355$. 